\title{
Death of a Nation? Debating the Great Transatlantic Emigration from Hungary, 1900-1914
}

\section{István Kornél Vida}

\begin{abstract}
The turn of the nineteenth and twentieth century was witness to an unprecedented wave of emigration from East Central Europe, with an estimated 1-1.5 million people leaving for the United States from the territory of Hungary. Such loss of population, mostly young males in their prime, shocked the nation and served as a subject for discussion in various forms and on multiple levels of discourse, from the newspaper reports through literary depictions, to scholarly publications and conferences. In this paper I examine significant monographs as well as conference volumes and proceedings, analyzing the major opinions and debates surrounding the causes and consequences of the Great Transatlantic Emigration. I discuss the most significant publications that appeared before the coming of the First World War, which put an end to mass emigration from Europe. These works in a sense represented the best that Hungarian migration studies had to offer for more than half a century, which makes them particulary worthy of scholarly attention.
\end{abstract}

Keywords: Migration history, Hungarian emigration to the United States, Hungarian-American links

Biography: István Kornél Vida is Assistant Professor in the North American Department of the Institute of English and American Studies, University of Debrecen, Hungary. He earned his Ph.D. in History in 2008 at the University of Debrecen. His research interests include nineteenth-century history of the United States, with particular focus on the Civil War era and migration history, as well as Hungarian-American history. He has published two monographs on the Hungarian Forty-Eighters' involvement in the American Civil War, including Hungarian Émigrés in the American Civil War: A History and Biographical Dictionary (2011). He is co-founder (2012) and Secretary of the Center for International Migration Studies in Debrecen. He is currently working on a new monograph on the historical memory of the Great Transatlantic Emigration in Hungary.

The first decade of the twentieth century saw an unprecedented wave of emigration from Hungary with most of those leaving the country heading for the United States. Although the influx of "New Immigrants" started as early as the 1880's, the majority of newcomers arrived

${ }^{1}$ This research was supported by the European Union and the State of Hungary, co-financed by the European Social Fund in the framework of TÁMOP 4.2.4. A/2-11-1-2012-0001 'National Excellence Program'."

(cc) $\mathrm{Br}$ ULIS D-Serle
New articles in this journal are licensed under a Creative Commons Attribution 4.0 International License.

This journal is published by the University Library System of the University of Pittsburgh as part of its D-Scribe Digital Publishing Program and is cosponsored by the University of Pittsburgh Press 
Vida, István Kornél. "Death of a Nation? Debating the Great Transatlantic Emigration from Hungary, 1900-1914." Hungarian Cultural Studies. e-Journal of the American Hungarian Educators Association, Volume 7 (2014): http://ahea.pitt.edu DOI: 10.5195/ahea.2014.144

after 1899. Between 1899 and 1913 approximately three million immigrants from AustriaHungary were registered by the United States Office of Immigration, with an estimated 1-1.5 million migrants from Hungary (United States Annual Report 1976: 62-64). The most intense years of emigration from the territory of Hungary were 1905, 1906 and 1907 with 7.9, 9.1, and 9.3 emigrants per 1,000 inhabitants, respectively. This was three times higher than during the previous years and almost five times as high as the average of the upcoming years until World War One (Puskás 2000: 21).

Mass emigration of this magnitude, of course, raised the attention of many in Hungary, both among the public and in academia. The discussion of the possible causes and consequences of emigration was present virtually everywhere, from the dramatic newspaper articles shocking the readers with accounts listing statistical data, through literary works prophesizing the demise of the nation, to scholarly discussions. A detailed analysis of all the various forms and levels of contemporary discourse on emigration goes well beyond the scope of this paper, and, therefore, I shall focus only on the scholarly discussion of emigration. In my view, this period marked not only the beginnings of serious, academic-level migration studies in Hungary in general, but, in a sense, was already at the peak of scholarly discourse on transatlantic migration from Hungary.

The discussion of the possible causes of mass emigration did not appear in scholarly works only. Politicians also sought explanations for it, which was clearly reflected in the early pieces of legislation regulating emigration. The early phase of Hungarian mass emigration, that is, the period between 1880 and 1900, seemed easy to handle, both for the the national government as well as local authorities, which found a scapegoat in the emigration agents who were allegedly recruiting emigrants in large numbers, typically for shipping companies. In 1881 a bill was passed with the title A kivándorlási ügynökségekröl ['On Emigration Agents'] which required emigration agents to acquire a license from the authorities, with those continuing their activities without such license facing fines and/or imprisonment.

As the new law provided no remedy for the constantly increasing emigration, the government found itself in a very inconvenient situation. The great landowners, whose political influence was commensurate with their economic dominance, demanded that steps be taken to prevent the cheap labor force leaving the country en masse. They requested that the government's laissez-faire approach to emigration be put to an end, with many advocating closing the borders completely. However, the government did not intend to interfere more directly with emigration, because it considered emigration a right, as it had clearly expressed in the Preamble to the bill on emigration agents: "Contemporary thinking does not allow the outright prohibition of emigration, for, as we all know, the right to emigrate is a constitutional right" [A kivándorlást egyáltalán betiltani a mai kor fogalmai szerint nem lehet, hiszen tudjuk, hogy a kivándorlási jog egyes államok alkotmányában biztosított jogot képez] (quoted in Puskás 1982b: 132). In addition, the government considered it advantageous from the perspective of the Hungarian nation-state that non-Magyars were leaving the country in large numbers, thus artificially increasing the percentage of the ethnic Magyar population. In 1880, the percentage of Magyars in Hungary was $46.6 \%$, which increased to $54.5 \%$ by 1910 . The proportion of all major non-Magyar ethnic groups decreased during the same period: the Germans (from $13.6 \%$ to $10.4 \%$ ), the Slovaks (from $13.5 \%$ to $10.7 \%$ ), and the Romanians (from $17.5 \%$ to $16.1 \%$ ) (Beluszky 2005: 268). Kunó Klebersberg pointed out to Prime Minister Kálmán Széll in 1902 that the mass emigration of the non-Hungarian population made up for the diminishing natural increase of the Magyar population (Puskás 2000: 90). 
Vida, István Kornél. "Death of a Nation? Debating the Great Transatlantic Emigration from Hungary, 1900-1914." Hungarian Cultural Studies. e-Journal of the American Hungarian Educators Association, Volume 7 (2014): http://ahea.pitt.edu DOI: 10.5195/ahea.2014.144

The government's efforts to see as many members of the unwanted ethnic groups as possible to leave provides an explanation for the fact that, despite its anti-immigration rhetoric, the Hungarian government always resisted the anti-emigration pressure groups and never went as far as prohibiting emigration. Although it did pass two new pieces of emigration legislation (in 1903 and 1909), these proved to be futile in even slowing down the tide of emigrants, much less stopping it completely. Even more interesting is that the Hungarian government signed a contract with the Cunard Steam Ship Company of Liverpool in which the company agreed to start a direct line from Fiume to New York to transport Hungarian emigrants directly from the territory of Austria-Hungary. Cunard accepted Hungarian governmental control over the emigrants (through issuing permits and passports, regulating the distribution of information material, employing inspectors at ports of departure), with the Hungarian government, in return, guaranteeing an annual number of 30,000 emigrants. Széll left no doubt regarding his motivation for promoting the contract with the Cunard:

I will declare that the idea behind this... has always been that the emigration traffic which presently goes through German ports should be directed toward our own port, Fiume, so that those who till now enriched the German ports should not go there, but to Fiume" (quoted in Puskás 2000: 91).

[Kijelentem, hogy igenis, mindig úgy kontempláltam a dolgot, hogy azok a kivándorlók, akik eddig a német kikötöket gazdagitották, ne oda menjenek, hanem a Fiuméban, a magunk kikötöjébe.]

When the government signed the contract with Cunard to deliver to them emigrant passengers, it again found itself in the crossfire of criticism, with the landowners' pressure groups attacking it for not banning emigration entirely, while at the same time the Social Democrats attacked the law, claiming that the law seriously curbed personal liberties, as potential emigrants could not decide on their preferred route freely. Individual counties in Hungary, especially the ones in the Northeastern part of the country, which were hit particularly hard by the mass emigration, also demanded that the government take steps to bar emigration. The government, however, instead of investigating the social and economic causes of emigration, sought and found scapegoats in emigration agents, as clearly reflected in the antiemigration agent bills of 1881 and 1903. In the official rhetoric, their activities were "draining the nation's energy," as Prime Minister Széll put it, and the perception prevailed that the emigration agents were almost exclusively Jewish. As Tara Zhara points out in her article on East Central European emigration agent trials, "anti-semitism did not cause the emigration panic. The role of Jews as brokers in the migration business did, however, fan the fires of Eastern European anti-Semitism, while anti-Semitism deepened popular and official anxieties about emigration." As she further states, "the history of emigration suggests that anti-Semitism was also specifically linked to the perceived role of Jews as movers of people and commodifiers of labour for a global market" (Zhara 2014: 161). The local press in Hungary also frequently reported cases of alleged emigration agents being arrested, although in fact many of these arrests ended with the suspect's acquittal in the absence of conclusive evidence. The public debate was dominated by similar scapegoating. As Julianna Puskás points out: 
Vida, István Kornél. "Death of a Nation? Debating the Great Transatlantic Emigration from Hungary, 1900-1914." Hungarian Cultural Studies. e-Journal of the American Hungarian Educators Association, Volume 7 (2014): http://ahea.pitt.edu DOI: 10.5195/ahea.2014.144

The government blamed the foreign shipping companies; the agrarians and the mercantilists blamed one another; the Social Democrats and the bourgeois radicals blamed the lords of semi-feudal Hungary, the big landowners and the big industrialists; and the leaders of the minority nationalities blamed the oppressive national policies of Vienna and Budapest (Puskás 2000, 95).

The interest of the Hungarian public as well as the sense of unavoidable doom felt in the nation added to the vivid debates about emigration in the scholarly community as well. The possible causes and consequences of the 'Great Transatlantic Emigration' were analyzed in dozens of books and articles, and many lectures, conferences, and symposia were organized by the government and professional organizations, as well as by regional and local administrations to address the issue. Participating in these debates were the crème de la crème of the contemporary scholarly community of demographers, sociologists, and economists. There were also other works which were "pre-ordered" by the government and reflected the official rhetoric concerning emigration. What follows is a brief analysis of some of the prominent approaches and stances represented in the works appearing during the peak years of emigration.

Arguably the pre-eminent experts of the epoch of demographic processes, migration studies, and the economic effects of these forces were Gusztáv Thirring (1861-1941) and Lóránt Hegedüs (1872-1943), both of whom actively participated in the scholarly debates of the era. Hegedüs presented a relatively early evaluation of the emigration problem in his A magyarok kivándorlása Amerikába ('The Emigration of Hungarians to America') (1899), while Thirring's A magyarországi kivándorlás és a külföldi magyarság ('Emigration from Hungary and Hungarians Abroad') came out in 1904. Both volumes proved to be the authorative works on the subject until the publication of Julianna Puskás' several contributions to the literature of the subject seven decades later (Puskás 1970, 1974, 1982a, 1982b, 1990).

Lóránt Hegedüs, a university professor, economic politician, and writer, was a member of the Hungarian Academy of Sciences, and was affiliated during most of his career with the Department of Treasury. This affiliation secured him a rare opportunity to personally investigate the characteristics of transatlantic migration in the United States between 1896 and $1902 . \mathrm{He}$ even visited the immigration station at Ellis Island in 1898 (at which time the Barge Office was actually at a temporary location, as Ellis Island had been destroyed in a fire the previous year) and the Commissioner of Immigration allowed him to study the immigration inspection process. In the five days Hegedüs spent at the immigration station he listened to some 600 immigrants being interviewed, from which he recorded his impressions:

One immigrant was more interesting than the other: true study characters were pushing each other through the large wooden hall: in the Babel of talk, in the dramatic mixing of exhausted groups, an incomprehensible scale of poverty and determination revealed itself, from the Sicilian goatherd trying to save a toy horse for his child, who had sneaked onboard the ship at Gibraltar, to the old lady from Abauj County, who was amazed at my questions in Hungarian (Hegedüs 1899, 2).

[Mialatt ezek az érdekesnél érdekesebb, valóságos tanulmány-alakok végig lökdösték egymást a nagy fa-hangáron: a nyelvek bábeljében, a megtépett csoportok drámai keveredésében a nyomorúságnak és elszántságnak befoghatatlan skálája bontakozott ki, a gyermek-lovacskát mentö szicziliai 
Vida, István Kornél. "Death of a Nation? Debating the Great Transatlantic Emigration from Hungary, 1900-1914." Hungarian Cultural Studies. e-Journal of the American Hungarian Educators Association, Volume 7 (2014): http://ahea.pitt.edu DOI: 10.5195/ahea.2014.144

\section{kecskepásztortól, ki Gibraltárban szökött a hajóra, az öreg abaujmegyei asszonyig, ki magyar kérdéseimen álmélkodott.]}

Making use of his first-hand experience of the interview process, Hegedüs took measure of the severity of the emigration agents' activity and remarked that, although their activities were supposed to be considerable, he did not meet a single Hungarian emigrant who had left Hungary lured by these agents. Instead, these Hungarians had received other, more significant, sources of information about the United States from others in his village who had emigrated earlier (Hegedüs 1899: 5). According to Hegedüs's own estimates, in 1890 there were between two hundred and two hundred fifty thousand Hungarian immigrants living in the United States, a "scattered, aimlessly wandering mass of atoms" [szétszórt, szülo" anyagától eltépett, ide-oda vert atom-tömeg] (Hegedüs, 1899: 31).

In his report from Ellis Island Hegedüs discussed both Hungarian emigration and U.S. Immigration policies. He was highly critical of the Hungarian government whose approach to regulating emigration he deemed "defective, because it had not solved anything... [and] embittered people who totally turned against the Hungarian state and refused to hear about it when already in America" [Hibás azért, mert czélra nem vezetett... [és] elkeseríti az embereket, a kik ezzel nemcsak tökéletesen elfordulnak a magyar államtól és arról Amerikában sem akarnak tudni] (Hegedüs, 1899: 55). He concluded that all attempts were particularly defective because they addressed the problems only superficially.

As for U.S. immigration policies, Hegedüs argued that Hungarian immigrants in America were the primary targets of the newly-adopted restrictions on immigration. Nativists had joined forces to push Hungarian emigrants out of America. The prospect of massive remigration, he pointed out, raised a number of questions, as most of the socio-economic problems that had forced emigrants out of the country were still unsolved. Hegedüs personally visited several of the regions in Hungary from which the largest number of people had emigrated, and left no doubt about the true causes of emigration which were to be found in the domestic conditions in Hungary (Hegedüs 1899: 72).

In his conclusion, Hegedüs called for legal control of emigration and a comprehensive emigration policy in Hungary. At the same time, he urged the government to pay more attention to the Hungarian diaspora in America, to recognize the Hungarian settlements overseas and provide state protection for the settlements and as well as for all Hungarian emigrants. Another authority on transatlantic migration was Gusztáv Thirring, a pre-eminent geographer, statistician, and demographer, who, like Hegedüs, was a member of the Hungarian Academy of Sciences, and who played a major role in the creation of the statistical analysis of emigration from Hungary. From 1894 he was the deputy director of the Capital City Statistical Office, and its director between 1906 and 1926. As the President of the Hungarian Statistical Society, he could rely on his personal connections with the French Commission de la Statistique des Grandes Villes, the German Deutsche Statistische Gesellschaft and the American Statistical Society. In his publications and public lectures he argued that emigration was the most acute problem of the country and that correct statistical data was needed, particularly because the number of emigrants was often over- or underestimated in the debates.

In A magyarországi kivándorlás és a külföldi magyarság ['Emigration from Hungary and Hungarians Abroad'] (1904) Thirring sought to determine the exact magnitude of emigration. He made use of foreign statistical sources, such as passenger lists of European ports, and compared them to the available Hungarian ones. This was a particularly difficult task since there had been 
Vida, István Kornél. "Death of a Nation? Debating the Great Transatlantic Emigration from Hungary, 1900-1914." Hungarian Cultural Studies. e-Journal of the American Hungarian Educators Association, Volume 7 (2014): http://ahea.pitt.edu DOI: 10.5195/ahea.2014.144

no organized collection of statistical data in Hungary before 1899, except for some isolated efforts in some counties, for example Zemplén County. Thirring's approach to collecting statistics was also brand new as he aimed to analyze the entire migration process; he investigated not only the Hungarian diaspora but also the level of remigration, all the while realizing that many emigrants and remigrants simply did not show up in the official statistics since a large number of people left the country without ever applying for a passport. He was also a pioneer in advocating that, instead of studying the statistics of the entire country, it would be more revealing to consider those regions of the country from which there was heavy emigration. This method would render truer data on the characteristics of emigration.

In his theoretical introduction, Thirring identified three general types of human migrations: internal migration, colonization, and emigration. He judged the former two to be advantageous, but felt that emigration could never be for the good of the country since it interrupted the normal and natural increase of the population, thus diminishing the development of the state and threatening its status as a great power (Thirring 1904: 5), which he considered the major threat for Hungary.

Thirring also scrutinized the situtation of Hungarians living in the United States, relying heavily on Gyula Szávay's work Túl a tengeren ['Over the Sea'] (1900), which had been published before his own work, in which he introduced the most significant Hungarian communities overseas and presented, somewhat dramatically, the reasons why Hungarian emigrants had left Hungary, namely that they were victims of their own ignorance, of hunger for money, and even the propaganda activities of emigration agents (Glant 2013: 190):

Without any cultivation, professional qualification they set out for a new life, none of the elements of which they know. Ruined persons from agriculture and viticulture land under the Statue of Liberty and obtusely gaze in the air, waiting for their good luck. They struggle through the entangled labyrinth of disappointments and deceits, bodily and psychic agony until one day they find themselves at work. They get to some mine where from four in the morning they scrape the coal in the grave of the living, or sweat doing equally hard work at a factory to make a living (quoted in Thirring 1904, 346).

\section{[Minden müveltség, szakmai képzettség hijával nekimennek annak az új életnek, melynek semmiféle tengelyét, rugóját nem ismerik. Elpusztúlt földmíves és szölömives nép kiköt a new-yorki szabadságszobor alatt és értetlen bámúlattal nézi a levegöt, lesi a szerencsét. A csalódások és csalások egész szövevényén, a testi és lelki gyötrődés mindenféle kínján keresztül ütödik-verödik, mire egy nap munkában találja magát. Eljut valami bányába, a hol reggel négy órától kezdve kaparja az elevenek sírjában a szenet, vagy eljut valami gyárba, a hol hasonló nehéz munkában verejtékezik, hogy kenyerét megkeresse.]}

Regarding the hardships that the Hungarian emigrants endured overseas, Thirring shares the opinion of Tihamér Kohányi (1863-1913), one of the prominent and influential intellectual leaders of the Hungarian community overseas and founder of the most important HungarianAmerican newspaper Szabadság. Kohányi argued that often only the immigrants themselves were to blame for not succeeding in their new country because of their fear of being exposed to the English language, thus not learning English properly (Thirring 1904: 345). 
Vida, István Kornél. "Death of a Nation? Debating the Great Transatlantic Emigration from Hungary, 1900-1914." Hungarian Cultural Studies. e-Journal of the American Hungarian Educators Association, Volume 7 (2014): http://ahea.pitt.edu DOI: 10.5195/ahea.2014.144

While Thirring also blamed the Hungarian immigrants in American for their inability to learn English, he nevertheless also already worried about the process of assimilation of Hungarians in the United States. He argued that the Hungarian government needed to take steps to preserve the language and the culture of the emigrants in order to slow down the process of Americanization and provide an opportunity for those planning to return to reintegrate into the Hungarian society. Thirring considered the preservation of Hungarian language and culture among Hungarians in America as a most urgent task, quoting the article of Kálmán Kováts, a Catholic priest at McKeesport, Pennsylvania, who warned:

The fate of Hungarians in America will be that of the stream falling into the sea: after a while we will forever become the children of America in our language as well as hearts. For those; who have settled here for good, it is a false and unreachable hope that they will remain Hungarians forever in America, as well. No, they will not! Children who were born and brought up in America are already nine-tenths lost for the Hungarian nation (quoted in Thirring 1904, 355).

[Mi magyarok úgy fogunk Amerikában járni, miként a tengerbe ömlö folyam: idök multával úgy nyelvben, mint szívben Amerika gyermekeivé válunk örökre. Azért azokra nézve, a kik végleg itt telepedtek le, csak hiú álom és elérhetetlen ábránd az, hogy ök Amerikában is megmaradnak magyaroknak örökre. Dehogy! Az a gyermek, a ki Amerikában született és itt is nevelkedett már, a magyar nemzetre nézve kilencz tized részben elveszett.]

Although Thirring at times blames the emigrants for their own fate in America, he acknowledges that there are causes of mass emigration from Hungary, not just the emigrants' ignorance and hunger for land. He shares the opinion of Hegedüs in holding the government and the political elite at least partly responsible for not handling the most pressing economic and social problems properly, namely the shortage of land, unemployment, and over-taxation properly, which served as primary push-factors in emigration:

An even greater burden of shame on our statesmen: they were insensible to the poverty that gave the wanderer's staff into the hands of hundreds of thousands of our countrymen, and who remained totally indifferent to the tragedy of this process (Thirring 1904: 2).

[Még nagyobb vád illeti államférfiainkat, kiknek nem volt érzékük ama nyomor iránt, mely népünk százezreinek a kezébe nyomta a vándorbotot s kik közönyösek maradtak e szomorú jelenség láttára.]

In addition to the works of Hegedüs and Thirring, one more study of the transatlantic emigration is worthy of mention due to its professional approach and scholarly quality. A magyar nép állapota és az amerikai kivándorlás ['The Condition of the Hungarian People and the American Emigration'] by Bertalan Neményi (1892-1947) was published in 1911 and was awarded the Special Prize of the Hungarian Academy of Sciences. The book is based on thorough research of available statistical data and field work carried out in the main sending regions, but Neményi had the opportunity to carry out investigations in the United States only in 
Vida, István Kornél. "Death of a Nation? Debating the Great Transatlantic Emigration from Hungary, 1900-1914." Hungarian Cultural Studies. e-Journal of the American Hungarian Educators Association, Volume 7 (2014): http://ahea.pitt.edu DOI: 10.5195/ahea.2014.144

1914 (Magyar írók 2002: 372). In his book he studied the possible push factors forcing emigrants out of Hungary and to the United States, and concluded that, for the emigrants, America appeared as the golden country of freedom and opportunity. This picture was based not so much on the tempting propaganda of the ship agents, but primarily on the positive news received from relatives and acquaintances. These latter informants told them that skilled workers could find employment anywhere without giving proof of their qualification (Neményi 1911: 6).

As for the possible motivations for emigration, Neményi argued that the deficient land structure which caused "the general hunger for land" in Hungary and the tax system were to blame and concluded that emigration was rooted in the depth of the country's economic and social system, but no single cause could be identified, but rather the combination of many factors (Neményi 1911: 40). He criticized heavily the Parliament for the severity of the problem stating that, instead of addressing the core socio-economic problems, it had passed two laws regulating the activities of emigration agents, although measures to satisfy people's hunger for land would have been more urgent (Neményi 1911: 14). Similarly to Hegedüs and Thirring, Neményi played down the impact of agents in persuading empoverished Hungarians to emigrate, arguing that they were not the ones to blame for mass emigration:

How much we have heard about them, read about them in the newspapers!... Local papers castigate the agencies in their headlines and hold them responsible for everything sad and desperate in our economic conditions" (Neményi 1911,12).

\section{[Mennyit hallottunk már ezekröl; mennyit olvasunk róluk naponként az újságokban...Helyi lapok vezércikkekben árasztják el szidalmaikkal az ügynökségeket, melyeket felelössé tesznek mindazért, ami szomorú és keseregni való a mi gazdasági viszonyainkban van.]}

Neményi opined that ordinary emigrants were incapable of making rational judgments about their futures since they were uneducated and often even illiterate: "How could they make a sober, mature judgment of their situation and conditions in America... when one out of four emigrants is illiterate, what is more, earth-bound and narrow-minded" [Hogyan is volna képes józan, érett itéletet alkotni magának a saját helyzetéröl s az amerikai viszonyokról, mikor negyedrészben analfabéta s azonfölül is röghöz tapadt, szük látókörü?] (Neményi 1911:3)? The ignorance of ordinary people, according to him, might provide an explanation as to how emigration fever spreads in the villages so much so that there are settlements where all young male inhabitants had been to the United States at least once (Neményi 1911: 6). In somewhat contradicting himself, he also points out that there are very effective communication channels between the sending and the receiving regions, consequently, ignorant or not, prospective emigrants usually had a very clear conception of employment opportunities, as well as wage levels, at least in the regions where their friends and acquaintances had settled. According to Neményi, the most important pull factor for those wanting to emigrate was the positive example offered by earlier emigrants with their increased wealth, newly-built houses, luxurious clothing and hearty meals (Neményi, 1911: 14), although he considered these as exceptions and argued that America would eventually disappoint most of the emigrants. 
Vida, István Kornél. "Death of a Nation? Debating the Great Transatlantic Emigration from Hungary, 1900-1914." Hungarian Cultural Studies. e-Journal of the American Hungarian Educators Association, Volume 7 (2014): http://ahea.pitt.edu DOI: 10.5195/ahea.2014.144

Fundamentally different from the publications of the previously discussed three authors, Hegedüs, Thirring, and Neményi, is the work of Andor Löherer. An economics writer, Löherer was a member of the Board of Directors of Gazdaszövetség [Farmers' Association] and Országos Magyar Gazdasági Egyesület [Hungarian National Economic Association], who published his Az amerikai kivándorlás és a visszavándorlás ['American Emigration and Return Migration'] in 1908. This was intended as an anti-emigration and anti-America propaganda book, of which historian László Horváth (2001:325) could only remark ironically:

If one pages through the comparative analysis of the conditions in Hungary and the United States one does not understand why the Americans were not the ones wanting to settle in Hungary by the hundreds of thousands" (Horváth 2001:325).

[Ha valaki...végiglapozta a hazai és az Egyesült Államokbeli állapotok összehasonlító elemzését, azt nem érti, hogy miért nem az amerikaiak igyekeztek százezer szám Magyarországon letelepedni.]

Löherer blamed the Hungarian emigrants' ignorance for the many personal tragedies overseas, because, he says, the "half-witted peasant thinks that in America money grows on trees, but only when he arrives there will he realize that the tree is so thorny that it will tear his body apart and only the pain will make him realize the truth" [A mi együgyü parasztunk azt hiszi, hogy Amerikában minden sövény kolbászból van fonva, pedig ha oda ér, akkor látja csak, hogy a sövény csak neki szól és olyan tüskés, mely testét cafatokká tépi s csak fájdalmában ébred a valóra] (Löherer 1908: 22-23). In the United States described by Löherer, corruption and crime flourished, and the living and working conditions of the immigrants were horrible:

In America, in the country of terrible selfishness, where the cool spirit of business pervades the old and the young alike, where everybody is after his or her fortune, there is no mercy, there is no good friend, relative, patron, there is no free milk, bread - it is horrible to be hungry. To avoid this, one cannot refuse any disgusting or impossible work" (Löherer 1908: 27-28).

[Amerikában, a rettenetes önzés hazájában, ahol az amerikai rideg üzleti szellem hat át öreget és fiatalt, ahol mindenki a' szerencse után fut, nincsen könyörület, nincsen jó barát, nincsen rokon, nincsen pártfogó, nincsen ingyen tej és ingyen kenyér s végre is éhen lenni borzasztó. Ezt elkerülendö, semmiféle undoritó vagy lehetetlen munkát sem lehet visszautasítani].

Löherer quotes several letters allegedly written by Hungarians in the United States or by remigrants (the senders of the letters are not mentioned by name), which draw a very negative picture of America, with one of them calling New York "the Cemetery of Hungarians" (Löherer 1908: 59-60). Löherer writes about the economic depression of 1907, based on his personal interviews with remigrants in Fiume. He claimed that most of them highlighted only their negative experiences, adding up to a collection of stories of failure. The one success story Löherer does include about József Possert is presented as impossible, because his salary of fiftyfive dollars a week that Prossert claimed to have earned, and which enabled him to save five thousand crowns in a year and a half, would have equaled the salary of a minister in the 
Vida, István Kornél. "Death of a Nation? Debating the Great Transatlantic Emigration from Hungary, 1900-1914." Hungarian Cultural Studies. e-Journal of the American Hungarian Educators Association, Volume 7 (2014): http://ahea.pitt.edu DOI: 10.5195/ahea.2014.144

Hungarian government (101). (In reality, skilled industrial workers were often in high demand and Possert could easily earn the mentioned amount.) In his anti-emigration propaganda book, Löherer concluded with high drama that the American soil was spoiled by Hungarian blood and thousands of Hungarian immigrants lost their lives working there (Löherer, 1908: 61).

Although Löherer was ready to acknowledge the importance of "America-letters," letters written by earlier emigrants to friends and relatives at home, bragging about their success, and luring new immigrants to America, he saw selfish motivations behind these.-Many Hungarian emigrants had opened boarding houses, for which they needed new "customers." This, according to Löherer, was the real motivation behind the letters written to friends and family members back home. Furthermore, he contends, many of the letters were actually written by American agents and exchangers, and not by the often illiterate emigrants. (Löherer 1908: 104, 112).

Löherer did not question the government's scapegoating regarding the activities of emigration agents and estimated the number of those lured by these agents to America to be approximately 150,000 each year. What is more, he identified many "remigrants" as playing a key role in propagating America and emigration as the well-meaning agents of emigration, while he accused others of actually being secret emigration agents employed by American corporations (Löherer 1908: 237-238). To further discourage people from contemplating emigration, Löherer listed a number of negative aspects of living and working in the United States from the unbearable climate to falling victim to cheaters, to performing such humiliating and disgusting work as the boarding mistresses having to soap the backs of their boarders. In the final chapter of his book, Löherer praised the government's efforts in initiating social and economic reforms in the country, which, according to him, would soon put transatlantic emigration to an end and enable people to return and reintegrate into Hungarian society (Löherer 1908: 257).

In addition to books and articles, perhaps the most significant forum for the exchange of ideas regarding the causes and consequences of transatlantic emigration were the conferences and meetings organized by various associations and organizations, namely the Országos Magyar Gazdasági Egyesület ['Hungarian National Economic Association'], Magyar Közgazdasági Társaság ['Hungarian Association for Economics'], Magyar Földrajzi Társaság ['Hungarian Geographical Association'], and Országos Nemzeti Szövetség ['Hungarian National Union']. Besides the regional emigration conferences, probably the most inluential professional symposium was organized by the Magyar Gyáriparosok Országos Szövetsége ['National Association of Hungarian Industrialists'] between June 19 and June 22, 1907. The proceedings of the meeting were published by the Association in a single volume entitled A kivándorlás: a Magyar Gyáriparosok Országos Szövetsége által tartott országos ankét tárgyalásai ['Emigration: The Discussions at the Meeting Organized by the National Association of Hungarian Industrialists'] which reflects closely questions and debates surrounding contemporary transatlantic emigration. Participating at the event were representatives of the government, local authorities, regional industrialists as well as leading experts on migration (among them Hegedüs and Thirring, the former being the Director of the National Association of Hungarian Industrialists, as well.)

In the introduction to the volume, emigration was mentioned as a deadly danger to the whole nation, which had attacked the entire economic life of the country and brought industrial development to a halt (A kivándorlás, 1907: 3). The symposium sought answers to the question of how emigration could be stopped and how its negative consequences could be handled. As a preparation, a circular was sent to the regional units of the associations with five questions: 
Vida, István Kornél. "Death of a Nation? Debating the Great Transatlantic Emigration from Hungary, 1900-1914." Hungarian Cultural Studies. e-Journal of the American Hungarian Educators Association, Volume 7 (2014): http://ahea.pitt.edu DOI: 10.5195/ahea.2014.144

1. Could the volume of emigration be decreased by changing the Emigration Act of 1903 and the Passport Act of 1903 and, and if it could, through what regulation?

2. What are the main problems with enforcing the Emigration Act; is the Cunard contract acceptable?

3. Are increasing state and local taxes connected with emigration; if yes, how could state expenditures be decreased and how should the tax system be reformed?

4. Which economic or administrative barriers to the development of industry should be removed?

5. To what extent would granting the workers land put an end to the lack of workers (A kivándorlás 1907: 5)?

All regional units submitted a written response to the questions and came up with their own ideas about how to best cope with the more and more acute problem of emigration. In his opening speech, Lóránt Hegedüs, as the director of the Association, submitted his own recommendations. He expressed his belief that emigration could and should not be curbed with administrative measures; therefore, there was no point in changing the emigration act. Instead, the Secretary of the Interior should rely on the Emigration Council (formed in 1904) and make sure that the U.S. Immigration Act of 1893, requiring each shipping company to inform the emigrants about the immigration requirements of the United States before their departure, be enforced. According to Hegedüs, the Cunard contract should be changed and all the permits of emigration agencies should be revoked. Furthermore, the immediate way to address the problem was by changing the tax system and do away with Income Taxes Class I and II which placed a disproportionately heavy burden on the working class. The association also promoted the development of industry in Hungary along with measures taken to advance the welfare of the workers. Lastly, a major land reform should be initiated so that the working families' hunger for land could be satisfied, as this is the major motivation "pushing" many of them out of the country (A kivándorlás 1907: 6-8).

During the two-day meeting, all the regional units and invited experts could share their views concerning both the causes and the consequences of this massive wave of emigration to the United States. Most of them agreed with Hegedüs regarding the possible remedies. In his concluding remarks, he said that he did not expect the regulating measures to have any significant results, as a "silent revolution" was taking place in Hungary, which had its roots in the acute internal problems of the country (A kivándorlás 1907: 387). Ferencz Chorin, presiding over the meeting, pointed out in his summary of the propositions of the meeting that it was agreed on that further regulation of the emigration agents' activity was necessary and all licenses were to be revoked. Also, the workers' income taxes should be repealed, and the communal tax system should more fairly reflect the sizes of the estates. The association proposed the establishment of a central agency which would supervise all anti-emigration propaganda activities and prepare booklets discouraging prospective emigrants by emphasizing the negative aspects of living and working in the United States. Similarly, the Department of Interior should handle all passport applications, except for the Southern counties and Transylvania. Steps should be taken to promote the welfare of workers by improving their living conditions and healthcare (A kivándorlás 1907: 409-415). 
Vida, István Kornél. "Death of a Nation? Debating the Great Transatlantic Emigration from Hungary, 1900-1914." Hungarian Cultural Studies. e-Journal of the American Hungarian Educators Association, Volume 7 (2014): http://ahea.pitt.edu DOI: 10.5195/ahea.2014.144

During the peak years, emigration conferences were organized not only by the associations, but also by the regions, which served as the primary sending areas for massive emigration. In 1902-1903 there were four such symposia studying emigration from UpperHungary, the Transdanubian Region, Southern Hungary and Szeklerland (Hegedüs 1904: 177198). All four were organized by the Hungarian National Economic Association, and thus their conclusions, besides describing the regional characteristics, pointed to the same direction. What is more, these conclusions usually coincided with those made by the meetings organized by other economic associations. One of the most important deficiencies of these congresses was that they focused almost exclusively on the conditions in Hungary and were not based on any significant research on the Hungarian diaspora in the United States. Consequently, as Hegedüs pointed out in his review of the results of the emigration congresses, half of the questions about emigration remained unaddressed (Hegedüs 1904: 179).

Although the first decade of the twentieth century saw the best of what Hungarian migration research could offer, the public was often not content with this. Many thought that, despite the proliferation of the published books and articles, organized meetings and conferences, the number of emigrants appeared to be rising unstoppably and they blamed the researchers as well as the authorities for not doing everything they could to stop this trend. For example, the press in Heves County, one of the major sending areas, frequently expressed harsh criticism:

Sometimes eager-beavers study the great social malady, writing only vague phrases and forcing their stupid ideas on the people discussing the causes of emigration: gibbering about people being soullessly incited, lured into emigration, without having the faintest idea what they are talking about ("A kivándorlásról" 1907: 4).

[Üres frázispuffogtató stréberek foglalkoznak olykor a nagy társadalmi betegséggel s a legzöldebb hülyeségekkel traktálják az ország népét beszélvén a kivándorlás okairól: kivándorlásra való csábitásról, lelketlen izgatásról makogva anélkül, hogy halvány fogalmuk volna arról, hogy mit beszélnek].

Another newspaper, the Hevesvármegyei Hírlap ('Heves County Newsletter') agreed:

Those studying emigration refer to this and that, interview everybody except those who are the most competent: the emigrants themselves. They are available and they would need to be asked to provide answers. What is more, they can supply information even without being asked: in the form of complaints and wailing" (“Levél Amerikából” 1903, 1-2).

[A kivándorlással foglalkozók] hivatkoznak erre-arra, megkérdeznek mindenkit, csak azt nem, aki a legilletékesebb: a kivándorló népet. Pedig itt van elöttünk s csak szavukba kerülne, hogy feleletet kapjanak. Söt kérdés nélkül is kapnak felvilágositást: panasz, jajgatás alakjában). 
Vida, István Kornél. "Death of a Nation? Debating the Great Transatlantic Emigration from Hungary, 1900-1914." Hungarian Cultural Studies. e-Journal of the American Hungarian Educators Association, Volume 7 (2014): http://ahea.pitt.edu DOI: 10.5195/ahea.2014.144

The newspaper regarded these meetings as pointless:

So far the Hungarian way of seeking the remedy has taken place, the so-called skull sessions. They have been seeking the causes of emigration, but, of course, have not been able to find them. One meeting identifies very wisely one thing as the cause of emigration, whereas another one some other" (A kivándorlás 1904, $1)$.

[[Eddig folyt] az orvosság keresésének magyar módja, az úgynevezett ankettezés. Keresték a kivándorlás okait, de persze nem találták meg. Az egyik szaktanácskozás bölcsen ezt, a másik még bölcsebben amazt állítja a kivándorlás okának.]

Similarly critical of both migration experts and politicians was Sándor Tonelli (18821950), a young sociologist and economics publicist. He had studied law at the University of Budapest and earned a doctorate, and had a keen interest in revealing the real causes and consequences of the mass exodus from Hungary (Vida 2013: 141-157). As a sociologist, he was well trained in the application of qualitative research methods and became convinced that the only way to take the true measure of the volume of emigration was through direct observation, something the government commissioners had neither the chance nor the inclination to do:

Members of Parliament only saw a breathing emigrant when they leaned their elbows on the hand-rails of the first or the second class deck and saw the Hungarians heading for America bustle about below them. They did not have the chance to familiarize themselves with the life of those in steerage, their treatment and the services and treatment they received" (Tonelli 1929, 10).

[A tanulmányutas képviselók eleven kivándorlót csak akkor láttak, ha kikönyököltek az elsö vagy második fedélzet korlátján és maguk alatt látták nyüzsögni az Amerika felé törekvö magyarokat. Hogy a fedélköz életét, az ellátást, a bánásmódot is megismerjék, arra nem volt alkalmuk.]

Tonelli concluded that the life of emigrants and their motivations could be revealed only if somebody undertook to travel with them in steerage, disguised as an emigrant, and visited the Hungarian settlements overseas (Tonelli 1929: 12). He took on himself this task: he secured a fake passport, disguised himself as an assistant photographer and on November 26, 1907 left Fiume heading for New York onboard the Cunard steamer Ultonia, sharing the steerage with other 1,278 emigrants. He described the aim of his trip as follows:

I intended to gather possibly exact personal data of as many people as possible on the ship and in America, to learn what had motivated them to emigrate, how they lived overseas, how much money they could send back home, so that I could make suggestions regarding the management of the issue of emigration armed with these data (Tonelli 1929: 92). 
Vida, István Kornél. "Death of a Nation? Debating the Great Transatlantic Emigration from Hungary, 1900-1914." Hungarian Cultural Studies. e-Journal of the American Hungarian Educators Association, Volume 7 (2014): http://ahea.pitt.edu DOI: 10.5195/ahea.2014.144

\section{[Össze akartam szedni a hajón és Amerikában minél több embernek lehetöleg pontos személyi adatait, hogy mi vitte öket a kivándorlásra, hogy éltek odakint, mennyi pénzt küldtek haza, hogy ezen anyag birtokában tehessek javaslatot a kivándorlás kérdésének kezelésére.]}

What resulted from this irregular sociological fieldtrip was perhaps the most unique analysis of transatlantic emigration from Hungary. Tonelli's work is even more intriguing, because, as a disguised photographer, he was able to take photos onboard the ship, which is why he referred to his work as a "written photograph." Once back in Hungary, Tonelli sent a memorandum based on his notes and photographs to Count János Hadik, under-secretary of the Department of Interior, but they disappeared without a trace and apparently had no effect at all. Tonelli conducted hundreds of interviews with Hungarian and other East Central European emigrants and summarized his findings in a book entitled Ultonia: Egy kivándorló hajó története ['Ultonia: Story of an Emigrant Ship'] which, however, he published only more than two decades later.

Mass emigration from Hungary to the United States came to a complete halt with the outbreak of the First World War, which made crossing the Atlantic virtually impossible for East Central Europeans. The Hungarian government terminated its contract with the Cunard Shipping Company on October 26, 1914 putting an end to the direct connection between the ports of Fiume and New York as well. The debates surrounding emigration did continue, although, quite understandably, with much lower intensity. The most important questions were thereafter how to preserve the loyalty of emigrants who intended to return but were stranded in the United States as a result of the war, and whether a new wave of mass emigration could be expected after the end of the war. The five-member Emigration Council published its report on emigration and remigration in 1916 and predicted a significant wave of Hungarian-Americans returning to their homeland following the war, who would be induced by various motives: curiosity, romanticism of war, worrying about relatives who stayed at home, and the hope for increasing wages following the war (Sürgös teendök 1916: 14).

Massive remigration actually never happened. There were many Hungarians who did return, but even more decided to settle in the United States following the First World War. They were disheartened by the poverty in war-struck Hungary and many were unwilling to return to their villages which did not belong to Hungary anymore, as a result of the Trianon Peace Treaty. Similarly, emigration to the United States could never reach pre-war levels, as it took time for transatlantic transportation to return to normalcy and, by the time it had done so, the new nativist movement of the early twentieth century in the United States managed to secure severe restrictions on immigration. The Reed-Johnson Act of 1924 badly discriminated against East Central European and Southern European immigrants. The newly introduced quota system virtually put an end to 'New Immigration.' Transatlantic migration from Hungary stagnated to a very low level, a fact that was clearly reflected in the number and nature of published works on emigration in Hungary. With the exception of one or two guidebooks for prospective emigrants (which placed more and more emphasis on Canada), the great debates surrounding emigration in Hungary were over, and serious scholarly discussions of the subject would not re-appear until the 1970s, with the introduction of modern, yet limited, research of transatlantic migration. 
Vida, István Kornél. "Death of a Nation? Debating the Great Transatlantic Emigration from Hungary, 1900-1914."

Hungarian Cultural Studies. e-Journal of the American Hungarian Educators Association, Volume 7 (2014):

http://ahea.pitt.edu DOI: 10.5195/ahea.2014.144

\section{Works Cited}

A háború utáni sürgös teendők a kivándorlás és a visszavándorlás tárgyában. A Kivándorlási Tanács öttagú bizottságának jelentése ['Urgent Duties about Emigration and Remigration after the War. The Report of the five-member Emigration Council']. 1916. Budapest: Kivándorlási Tanács.

Beluszky, Pál. 2005. Magyarország történeti földrajza ['The Historical Geography of Hungary'] Budapest: Dialóg Campus Kiadó.

Glant, Tibor. 2013. Amerika, a csodák és csalódások földje. ['America, the Land of Wonders and Disappointment'] Debrecen University Press.

Hegedüs Lóránt. 1904. "A kivándorlási kongresszusok eredménye I." ['The Results of the Emigration Congresses, Part I'] Budapesti Szemle 325: 177-198.

Hegedüs Lóránt. 1899. A magyarok kivándorlása Amerikába. ['The Emigration of Hungarians to America'] Budapest.

Horváth László. 2001. "A XX. századi Heves megyei kivándorlás alapvetése 1910-ig” ['The Fundamentals of twentieth century emigration from Heves County before 1910']. In Az egri Dobó István Vármúzeum Évkönyve. Eger: 297-336.

Immigration and Naturalization Service. 1976. United States Annual Report. Table 13, Washington, D.C.

A kivándorlás. A Magyar Gyáriparosok Országos Szövetsége által tartott országos ankét tárgyalásai ['Emigration: the Discussions at the Meeting Organized by the National Association of Hungarian Industrialists']. 1907. Budapest: Pesti-Lloyd Társulat.

“A kivándorlásról” [“About Emigration']. Gyöngyösi Újság (March 17, 1907): 4.

"Levél Amerikából" [“A Letter from America']. Hevesvármegyei Hírlap (June 26, 1903): 1-2.

Löherer, Andor. 1908. Az amerikai kivándorlás és a visszavándorlás [American Emigration and Return Migration]. Budapest: Pátria.

Magyar írók élete és munkái ['The Life and Works of Hungarian Writers’]. 2002. Budapest: Argumentum Kiadó.

Neményi, Bertalan. 1911. A magyar nép állapota és az amerikai kivándorlás ['The Condition of the Hungarian People and Emigration to America']. Budapest: Athaeneum.

Puskás, Julianna. 1970. “Magyar szervezetek Amerikában (az 1880-as évektől az 1960-as évekig)" ['Hungarian Organizations in America from the 1880s to the 1960s']. Történeti Szemle, 13: 528-568.

Puskás Julia, 1974. "Kivándorlás Magyarországról az USA-ba 1914 előttt” ['Emigration from Hungary to the USA before 1914']. Történeti Szemle 17: 32-67.

Puskás, Julianna. 1982a. From Hungary to the United States (1880-1914). Budapest: Akadémiai Kiadó.

_. 1982b. Kivándorló magyarok az Egyesült Államokban, 1880-1940. ['Hungarian Emigrants in the United States, 1880-1940']. Budapest: Akadémiai Kiadó.

-1990. Overseas Migration from East-Central and Southeastern Europe, 1880-1940. Budapest: Akadémiai Kiadó.

- 2000. Ties that Bind, Ties that Divide. New York: Holmes and Meier.

Szávay Gyula. 1900. Túl a tengeren ['Over the Sea']. Györ: Pannónia Könyvnyomda.

Thirring, Gusztáv. 1904. A magyarországi kivándorlás és a külföldi magyarság ['Emigration from Hungary and Hungarians Abroad']. Budapest. 
Vida, István Kornél. "Death of a Nation? Debating the Great Transatlantic Emigration from Hungary, 1900-1914." Hungarian Cultural Studies. e-Journal of the American Hungarian Educators Association, Volume 7 (2014):

Tonelli, Sándor. 1929. Ultonia: Egy kivándorló hajó története ['Ultonia: The Story of an Emigrant Vessel']. Budapest: Királyi Magyar Egyetemi Nyomda.

Vida, István Kornél. 2013. “'An Immigrant in Disguise': Sándor Tonelli’s Ultonia - A Written Photograph.” In East Central Europe in Exile. Volume I: Transatlantic Migrations. Ed. Anna Mazurkiewicz. Newcastle, UK: Cambridge Scholars Publishing, 2013, 141-156.

Zhara, Tara. 2014. "Travel Agents on Trial: Policing Mobility in East Central Europe, 18891989." Past and Present 223: 161-193. 